(С) Матохнюк М.О., Пашкова Ю.П., Жебель В.М.

УДК 616.12-008.331.1:[575.21+577.212+575.113]-055.1

DOI https://doi.org/10.31718/mep.2020.24.5-6.03

\title{
ФЕНОТИПОВИЙ ПОРТРЕТ ЕСЕНЦІАЛЬНОЇ ГІПЕРТЕНЗІЇ, ЯК ІНСТРУМЕНТ ПІДВИЩЕННЯ ЕФЕКТИВНОСТІ ЇЇ ДІАГНОСТИКИ ТА ПРОГРЕСУВАННЯ У ЧОЛОВІКІВ НОСІЇВ ПОЛIМОРФНИХ ВАРІАНТІВ ГЕНА КАРДІОТРОФІНА-1
}

Матохнюк М.О., Пашкова Ю.П., Жебель В.М.

Вінницький національний медичний університет ім. М.І. Пирогова, м. Вінниця, Україна

Метою дослідження є удосконалення ефективності діагностики прогресування ессенціальної гіпертензії (ЕГ) на основі кластерного аналізу, який базується на антропометричних, лабораторних та показниках системної та внутрішньосерцевої гемодинаміки у чоловіків 40-60 років. У дослідження були залучені 50 чоловіків з асимптомною ЕГ у віці- 50,62 00,73 років та 50 чоловіків з EГ, що ускладнена хронічною серцевою недостатністю (ХСН), у віці$51,86 \pm 0,81$ років. Усім учасникам дослідження виконували стандартне ехокардіографічне обстеження, визначали плазмові концентрації кардіотрофіна-1 (КT-1) в сироватці крові за допомогою імуноферментного аналізу (IФА) та поліморфізму (rs8046707) гена КТ-1 у зразках венозної крові методом полімеразної ланцюгової реакції (ПЛР). За допомогою кластерного аналізу виділено фенотиповий портрет пацієнта.

Ключові слова: есенціальна гіпертензія, хронічна серцева недостатність, кардіотрофін-1.

\section{Вступ}

Підвищений артеріальний тиск (АТ) є провідним фактором ризику глобального тягаря захворювань, із поширеністю $24 \%$ у чоловіків та $20 \%$ у жінок. Загалом - це близько 1,1 мільярда постраждалих дорослих у всьому світі. За оцінками, щорічно гіпертензія призводить до приблизно 9,4 мільйона смертей [1]. На сьогодні, згідно сучасним уявленням, есенціальна гіпертензія (ЕГ), як провідний фактор ризику розвитку серцево-судинних захворювань $є$ результат поєднання генетичних, екологічних та соціальних детермінант [2]. Як відомо, вона викликає структурні та функціональні зміни в серці, серед яких провідне місце займає гіпертрофрія лівого шлуночка (ГЛШ), які в кінцевому підсумку призводять до хронічної серцевої недостатності (XCH), що ще більше збільшує смертність таких хворих [3]. Зокрема, відомо, що серед пацієнтів 3 сфрормованою ХCH щорічна смертність коливається від 7\% для стабільних/амбулаторних пацієнтів до 17\% - серед стаціонарних хворих, а частота госпіталізацій за 12 місяців становить 44\% і 32\% відповідно [4].

Не зважаючи на велику кількість досліджень етіопатогенезу згаданих вище патологічних станів, недостатньо вивченими залишаються фрактори які сприяють їх виникненню та прогресуванню. Дана проблема актуальна особливо в тих випадках, коли відсутня достатня діагностика тих явищ, що призводять до погіршення стану пацієнтів та несприятливого прогнозу ЕГ. Сучасні інформаційні технології в комбінації з інструментальним та біомаркерним обстеженням у значній мірі полегшують вирішення питань прогнозування. В якості одного з біомаркерів, що можна використати для своєчасної діагностики та прогнозування розвитку ГЛШ при ЕГ розглядається кардіотрофін-1 (КТ-1), адже зміни його плазмової концентрації асоціюються як з гіпертрофією кардіоміоцитів так і з розвитком фібротичних процесів у мязі серця [5], а отже відбива- ють процес фрормування ГЛШ. Однак, експресія КТ-1 контролюється кодуючим геном, що теж необхідно враховувати в діагностичному процесі [6].

Вищезазначене $є$ підґрунтям використання для отримання відповідних діагностичних висновків методології управління кількома змінними та їх взаємодією. Один із напрямків це застосування кластерного аналізу - сукупності методів визначення підгруп осіб з високою гетерогенністю. Групування побудовані таким чином, що ступінь асоціації є сильною між членами одного кластеру та слабкою між членами різних кластерів [7]. Згідно даних літератури є припущення, що результати кластерного аналізу можуть сприяти до виявленню характеристик фенотипу захворювання [8], а отже спростити застосування в лікувальному процесі сучасних технологій обстеження та використання у роботі лікаря визначення плазмового рівня KT-1.

Метою проведенного дослідження $є$ удосконалення ефрективності діагностики прогресування ЕГ на основі кластерного аналізу, який базується на генетичних, антропометричних, гемодинамічних лабораторних показниках у чоловіків 40-60 років.

\section{Матеріали і методи дослідження}

Обстежено 50 чоловіків з асимптомною ЕГ середній вік яких $50,62 \pm 0,73$ років та 50 чоловіків 3 ЕГ ускладненою ХСН IIA, II-III ф.кл, середній вік $51,86 \pm 0,81$ років. Усі хворі спостерігалися та знаходились на стаціонарному лікуванні у Вінницькому обласному спеціалізованому клінічному диспансері протирадіаційного захисту населення МОЗ України і Військово-медичному клінічному центрі Центрального регіону Військово-повітряних сил України.

Критеріями виключення із дослідження був вторинний характер ЕГ, наявність захворювання нирок та печінки, хронічного обструктивного захворювання легень, новоутворень, заздалегідь відомі обстежуваним

\footnotetext{
* Цитування при атестації кадрів: Матохнюк М.О., Пашкова Ю.П., Жебель В.М. Фенотиповий портрет есенціальної гіпертензії, як інструмент підвищення ефективності ії діагностики та прогресування у чоловіків носіїв поліморфних варіантів гена кардіотрофіна-1. // Проблеми екології і медицини. - 2020. - Т. 24, № 5-6. - С. 11-13.
} 
особам ендокринні захворювання, хвороби системи крові та IXC, яка виникла до діагностування ЕГ. Вищеперераховані захворювання виключалися за допомогою збору скарг, результатів проведеного об'єктивного та загально-клінічного обстеження (в тому числі проведення, в разі необхідності, претестової діагностики (XC), а також детального аналізу амбулаторних карт.

Визначення поліморфізму гену кардіотрофріну-1 (rs8046707) проводили використовуючи метод полімеразної ланцюгової реакції. Генотипування гена КТ-1 проводилось спільно з НДІ генетичних та імунологічних основ розвитку патології та фрармакогенетики Української медичної стоматологічної академії (м. Полтава).

Концентрація КТ-1 в плазмі крові визначались за допомогою набору реактивів фрірми «RayBiotech, Inc» (США) методом імуноферментного аналізу на стриповому імуноферментному аналізаторі "Humareader single" (Німеччина).

Структурно-функціональні показники міокарда оцінювали за допомогою ультразвукового дослідження серця. За фоормулою de Simone для осіб з ускладненою та асимптомною ЕГ були розраховані належні значення іММЛШ- адекватна та неадекватна МЛШ, яка враховує такі показники- стать, зріст, вік та гемодинамічне навантаження лівого шлуночка.

Реєстрація ЕКГ проводилася за загальноприйнятою методикою у 12 стандартних відведеннях. Вимірювання артеріального тиску здійснювали згідно рекомендаціям експертів BOO3 та ESC/ESH, ACC/AHA, ISH (2016-2020). Математичну обробку матеріалу проводили на персональному комп'ютері 3 використанням стандартного статистичного пакету STATISTICA 10. Для ідентифрікації фенотипів пацієнтів використано кластерний аналіз, а саме методу К-середніх (K-means).

\section{Результати та їх обговорення}

Етіологія 92\%-95\% випадків есенціальної гіпертензії досі чітко не визначена. У людей, що страждають на ЕГ, зазвичай виявляють поєднання декількох генетично детермінованих відхилень, проте фенотипи цих порушень можуть коригуватися факторами зовнішнього середовища, способом життя і таким чином змінювати перебіг захворювання. Тому важливим у прогнозі і перспективним для пацієнта $€$ вплив на модифрікуючи фрактори ризику та їхня профрілактика $[2,9,10]$. За допомогою прямого покрокового аналізу для показників які можуть впливати на розвиток XCH на тлі ЕГ в матрицю для дискримінантного аналізу були включені інтервальні показники: вік, IMT, концентрація КТ-1 в плазмі крові, ХС ЛПНЩ, розмір ЛП, наявність, або відсутність ДД, неад. МЛШ, рівень САТ і ДАТ. Проведена оцінка отриманих результатів за допомогою аналізу величин $\Lambda$-Уїлкса $(0,13)$, X2 (311), а також Канонічний R $(0,95)$ - дозволяє вважати представлену модель корисною. наступним кроком дослідження стало проведення кластерного аналізу даних показників. Далі відібрані показники були переведені в інтервальну шкалу: вік 1- 40-50 років, 2 - 51-60 рік; маса тіла за допомогою формули розрахунку IMT- 1- нормальна, 2- надлишкова маса, 3-ожиріння; ХС ЛПНЩ відповідно до рекомендацій з діагностики та лікування дисліпідемій 1- < 2,6 ммоль/л, 2 ->2,6 ммоль/л, МЛШ1- адекватна МЛШ, 2 - неадекватна МЛШ; ЛП: 1- <4.0 см., 2 ->4,0 см.; ДД: 1 -нормальна, 2- діастолічна ди- сорункція І ст., 3- II ст., 4-III ст, АТ- 1-130-139/8589мм.рт.ст., 2-140-159/90-99 мм.рт.ст., 3- 160-179/100109мм.рт.ст., 4- $\geq 180 / \geq 110$ мм.рт.ст.. За допомогою ROC- аналізу розрахований межовий рівень КT-1 в плазмі крові- 303,81 пг/мл (чутливість-87,5\%, специфічність-92\%), тому відповідно 1-<303,81 пг/мл, 2$>303,81$ пг/мл. Далі була проведена стандартизація показників для подальшого аналізу. Обрано два кластери. Встановлено, що в 1 кластер увійшли 42 чоловіки з асимптомною ЕГ, а в кластер 2- 8 осіб з асимптомною ЕГ, та 50 осіб з ускладненою ЕГ. За допомогою кластерного портрета (рис. 1) визначається, що на кластер 2 припадають не лише вищі антропометричні, лабораторні та показники внутрішньосерцевої гемодинаміки, з якими повязують більш важкий перебіг ЕГ а й вища концентрація КТ-1 в плазмі крові. Що може свідчити про більш важкий перебіг захворювання у осіб які віднесені до 2-го кластеру. Таким чином, особи, яких можна припустити до другого варіанту фенотипу можуть мати гірший прогноз перебігу хвороби.

Однак, постає питання відносно вагомості визначення як плазмової концентрації КТ-1, так і варіанта генотипу кодуючого гена.

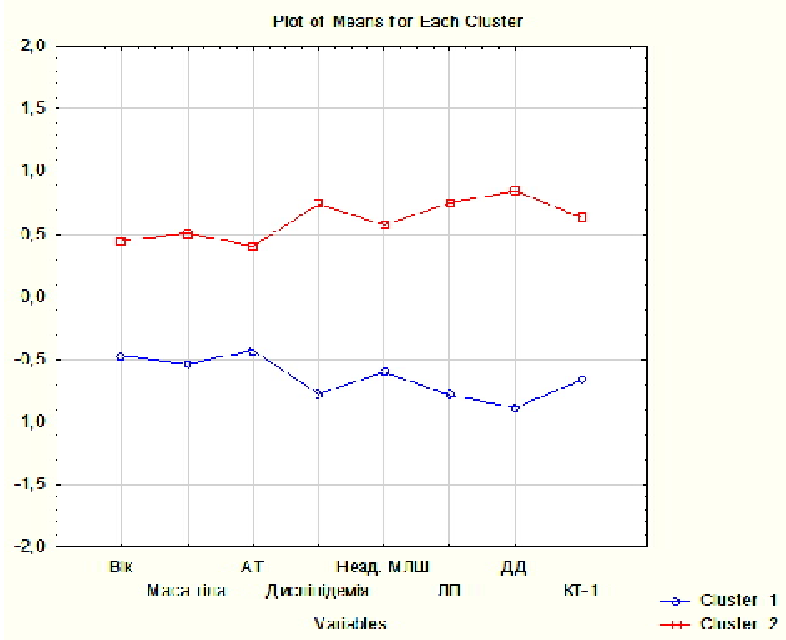

Puc. 1 Кластерний портрет- значення параметрів в межах розподілених кластерів

Наступним кроком дослідження стало вивчення частотного розподілу генотипів гена КТ-1 в даних кластерах (Табл.1). Розподіл частот генотипів гена КТ-1 у чоловіків хворих на ЕГ, мешканців Подільського регіону України, відповідав рівновазі Харді-Вайнберга. У зв'язку з низькою частотою зустрічаємості генотипу AA, осіб - носіїв генотипів, що носять алель A (GA i AA), було вирішено об'єднати в одну групу - носії генотипів GA+AA. Одже, серед пацієнтів, що увійшли до кластеру 2 переважають особи 3 генотипом GG+AA гена KT-1. Тобто можна припустити, що для осіб з генотипами GG+AA характерні вищі показники.

Табл. 1

Частота розподілу генотипів гена КТ-1 у кластерах, \%

\begin{tabular}{|c|c|c|c|}
\hline & $\begin{array}{c}\text { Генотип } \\
\text { GG }\end{array}$ & $\begin{array}{c}\text { Генотипи } \\
\text { GA +AA }\end{array}$ & $\mathrm{p}$ \\
\hline $\begin{array}{c}\text { Кластер 1 } \\
(\mathrm{n}=42)\end{array}$ & $\begin{array}{c}47,62 \\
(\mathrm{n}=20)\end{array}$ & $\begin{array}{c}52,38 \\
(\mathrm{n}=22)\end{array}$ & $\mathrm{p}>0,05$ \\
\hline $\begin{array}{c}\text { Кластер 2 } \\
(\mathrm{n}=58)\end{array}$ & $\begin{array}{c}25,86 \\
(\mathrm{n}=15)\end{array}$ & $\begin{array}{c}74,14 \\
(\mathrm{n}=43)\end{array}$ & $\mathrm{p}<0,05$ \\
\hline
\end{tabular}


Для більш точного відображення результатів дослідження та прикладної їх індивідуалізації для конкретного чоловіка з ЕГ застосовано лінійний дискримінантний аналізу по Фішеру із створенням математичної моделі прогнозу перебігу захворювання для осіб які віднесенні до 1 та 2-го кластера у вигляді схеми класифікаційних рівнянь. Модель прогнозу перебігу захворювання у чоловіків з асимптомною та ускладненою ЕГ 40-60 років, мешканців Подільського регіону України які увійшли в 1 та 2-ий кластер має наступний вигляд:

1. Кластер $1=-251,38+14,26$ * Вік $+3,63$ *ДД + 110,94 * ЛПНЩ - 0,036* КТ-1 +9,91*ЛП + 7,20 * АТ+ 4,76 *Маса тіла+3,31* Неад. Млш.

2. Кластер $2=-311,65+15,66^{*}$ Вік $+12,28$ *ДД + 118,53 * ЛПНЩ $-0,014 *$ КТ-1 +12,17 *ЛП + 7,95 * АТ+ 7,39 * Маса тіла+4,21* Неад. МлШ.

Модель достовірна при значенні (Willks' Lambda = $0,21 ; F=(7,92) 50,24 ; p=0,0001)$. Загальна точність методу склала $97.9 \%$, чутливість методу становить 95,55\%, специфічність - 90,29 \%. Прогноз перебігу захворювання пацієнта належатиме до того кластера, для якого класифрікаційне рівняння в порівнянні 3 іншим, буде вищим. Якщо отримане числове значення буде більшим у фрормулі (1) - це говорить про те, що пацієнт із ймовірністю 90,29 \%, - має кращий прогноз перебігу ЕГ різної тяжкості, а якщо числове значення буде більшим у формулі (2) - обстежуваний з ймовірністю 95,55 \% має ризик розвитку ХСН внаслідок ЕГ.

Кластерний аналіз, а саме k-means, досить широко поширений в різних галузях медицини і не тільки. Започаткували використання даного аналізу антропологи в 1911 році - Я. Чекановський та в 1932 році Driver i Kroeber. В 1944 р. метод починають широко використовувати для класифрікації теорії ознак в психології особистості [11]. Згідно даних літератури кластерний аналіз проводили і у хворих з ЕГ, а саме в китайській популяції для виявлення основних факторів розвитку ішемічної хвороби серця та ЕГ, на території Європи для визначення факторів які впливають на таке ускладнення ЕГ як інсульт $[8,12]$. Лозинська М.C. використала даний аналіз для виявлення фенотипового портрету у чоловіків з ЕГ носіїв поліморфних варіантів гена альдостеронсинтази [ Лозинська М. С.]. Дані отриманні в нашому дослідження свідчать про те, що чоловіки які увійшли до кластеру 2 мають більш несприятливий прогноз перебігу ЕГ. Серед них достовірно частіше зустрічаються носії генотипів $\mathrm{GA}+\mathrm{AA}(\mathrm{p}<0,05)$. Для практичного використання розраховані дискримінантні рівняння для кожного кластеру, у які увійшли не лише загальновідомі антропометричні, лабораторні та ехографічні показники, а й новий біомаркер КТ-1.

\section{Висновки}

1. За допомогою кластерного аналізу виділено френотиповий портрет пацієнта (кластер), в якому до відомих показників (вік, маса тіла, АТ, неад. МЛШ, ХC ЛПНЩ, ЛП, ДД) зростання яких характеризують гірший прогноз перебігу ЕГ додається більш висока концентрація КТ-1 в плазмі крові,

2. Серед чоловіків які мають більш неблагоприємний перебіг ЕГ частіше зустрічаються носії генотипів
GA+AA ( $<00,05)$, що може свідчити про несприятливий прогноз у носіїв цих варіантів генотипу гена КТ-1.

3. За допомогою дискримінантного аналізу по Фішеру створена математична модель для індивідуалізації прогнозу перебігу ЕГ у чоловіків.

\section{Література}

1. Sánez Tähtisalo H, Ruotsalainen S, Mars N, et al. Human essential hypertension: no significant association of polygenic risk scores with antihypertensive drug $\begin{array}{lllll}\text { responses. Sci } & \text { Rep } 2020 ; & 10: 11940\end{array}$ https://doi.org/10.1038/s41598-020-68878-3

2. Carey RM, Muntner P, Bosworth HB, Whelton PK. Prevention and Control of Hypertension: JACC Health Promotion Series. J Am Coll Cardiol. 2018;72(11):1278-1293. doi:10.1016/j.jacc.2018.07.008

3. Горопко О.Ю., Ожиріння та артеріальна гіпертензія: сучасні погляди на патогенез, діагностику та лікування. Семейная медицина 2019; 2(82):18-24

4. Скибчик В.А. Хронічна серцева недостатність: нові підходи до діагностики та лікування. Ліки України 2016; 10(206):34-41 9894.2016.10(206).207666

5. Pemberton CJ, Raudsepp SD, Yandle TG, et al. Plasma cardiotrophin-1 is elevated in human hypertension and stimulated by ventricular stretch. Cardiovasc Res 2005;68:109-17. 10.1016/j.cardiores.2005.05.014

6. Pennica D, Swanson TA, Shaw KJ, Kuang W J, et al. Human cardiotrophin-1: protein and gene structure, biological and binding activities, and chromosomal localization. Cytokine. 1996; 8(3):183-189. https://doi.org/10.1006/cyto.1996.0026

7. Weatherall M, Shirtcliffe $P$, Travers J, Beasley R. Use of cluster analysis to define COPD phenotypes. European Respiratory Journal 2010; 36 (3):472-474; DOI: 10.1183/09031936.00035210

8. Guo Q, Lu X, Gao Y. et al. Cluster analysis: a new approach for identification of underlying risk factors for coronary artery disease in essential hypertensive patients. Sci Rep 2017; 7: 43965. https://doi.org/10.1038/srep43965

9. Curfman G, Bauchner $\mathrm{H}$, Greenland P. Treatment and Control of Hypertension in 2020: The Need for Substantial Improvement. JAMA. 2020; 324(12):1166-1167. doi:10.1001/jama.2020.13322

10. Пашкова Ю.П. Поліморфізм гена мозкового натрійуретичного пептиду та плазмові концентрації М - та С - натрійуретичних пептидів у чоловіків з гіпертонічною хворобою, ускладненою хронічною серцевою недостатністю. Клінічне значення: автореф. дис. ... канд. мед. наук. Державна установа «Національний науковий центр «Інститут кардіології імені академіка М.Д. Стражеска» Національної академії медичних наук України, Київ, 2017.

11. Blashfield RK, Aldenderfer MS. The Methods and Problems of Cluster Analysis. In: Nesselroade J.R., Cattell R.B. (eds) Handbook of Multivariate Experimental Psychology. Perspectives on Individual Differences. Springer, Boston, MA. 1988 https://doi.org/10.1007/978-14613-0893-5 14

12. Aszalós Z, Barsi P, Vitrai J. et al. Hypertension and clusters of risk factors in different stroke subtypes (an analysis of Hungarian patients via Budapest Stroke Data Bank). J Hum Hypertens. 2002; 16:495-500 https://doi.org/10.1038/si.jhh.1001428

13. Лозинська М.С. Спадкові передумови ремоделювання міокарда у чоловіків 3 гіпертонічною хворобою, мешканців Подільського регіону. Діагностичне та клінічне значення. Клінічне значення: автореф. дис. ... доктора філософрі . Вінницького національного медичного університету ім. М. І. Пирогова МОЗ України, Вінниця, 2020

Матеріал надійшов до редакції 00.10.2020 